\title{
The life cycle of initial public offering companies in China
}

\section{Introduction}

Going public is an important new phase in the life cycle of a company during and beyond which it aspires to recycle more productively financial and physical resources (Liu et al., 2013). A body of literature investigates operating performance and stock returns following the initial public offering (IPO), and tends to indicate that companies underperform after the IPO relative to their pre-IPO performance (Jain and Kini, 1994; Wang and Deng; 2006; Chi et al., 2010). Notably, Fama and French (2004) find a dramatic decline in the survival rates of newly listed companies over several decades. These studies have directed increasing efforts in examining the survival and decline of IPO companies in their aftermarket.

A number of studies consider the survivorship of new listings seeking to account for subsequent delisting or acquisition (e.g., Campbell et al., 2008; Jain and Kini, 2008). Rising numbers of IPO's have triggered increasing research into why some IPO companies easily become a takeover target (e.g., Liu et al., 2013). One view holds that companies are delisted or acquired in the face of impending bankruptcy or violation of exchange regulation (De and Jindra, 2012). A different position is that companies are delisted or acquired due to their potential value or superior performance (Chi et al., 2010). In pursuit of their purpose, some studies endeavour to pinpoint predictive factors. Focusing on the company decline, Rao (1989) notes that one reason for the decline with the time is that companies take excessive risk in their undertakings. Jain and Kini (1999) demonstrate that higher company risk increases the probability of not surviving while reducing the probability of being acquired. Peristiani and Hong (2004) argue that the companies with negative pre-IPO earnings are three times more likely to be dropped from an exchange than profitable ones. Some studies find that outdated technology and lack of production focus threaten the company's continuity and hence its survival (Henning and Lu, 2000; Hovey and Li, 2009). With respect to acquisition, Palepu (1986) and Theodossiou et al. (1996) note that inefficiently managed companies are popular acquisition candidates because of their lower comparable profitability and probable financially distressed condition. Peel and Wilson (1989) and Gilson (1989), however, find that good performing companies are frequently subject to hostile targets and that the decision to acquire a distressed company is based mainly on synergistic grounds and the extent of 
financial distress of a company. Using an integrated approach, Jain and Kini (1994) consider what determines whether a company survives independently, fails outright, or becomes the subject of an acquisition after going public, and conclude that IPO features, industrial structure and corporate strategies determine the transition states. These above studies consider these issues from the issuer's perspective.

A growing literature examines corporate evolution following the IPO from the investor's perspective. Goergen (1998) and Mikkelson et al. (1997) examine the development of corporate ownership following the IPO with focus on shareholdings and board representation of venture-capital backers and identify the dynamic relationship between company performance and corporate ownership and governance structure. Other aspects of corporate governance of IPO companies, such as executive pay, have received some attention from researchers (Baker and Gompers, 2003). Holmstrom and Kaplan (2001) focus on the role of corporate governance in increased M\&A activity in a 20-year period of their study. Ang et al. (2000) note that managerial ownership reduces agency costs leading to value creation. Agency problems, however, are not restrained when there is a lack of independent directors, leading to company decline (Yermack, 1996; Dennis and McConnell, 2003). In the case of China, Wei et al. (2005) suggests that state shareholdings increase the tendency toward company decline. The opposite view holds that state ownership may facilitate company performance and thus enhance shareholder value (Wang and Deng, 2006). Guo and Brooks (2009) find evidence to support that state-owned shares are offered in a positive market sentiment. Concerning corporate governance attributes, Li and Cui (2003) contend that independent directors in China find it difficult to fulfill their monitoring role, because the boards are typically dominated by insiders and hardly have any outsider presence. By contrast, Chen et al. (2006), Wang and Deng (2006) and Zhao (2006) find that independent directors in China play a positive role in company performance.

Yet despite the progress thus far, previous studies are subject to a number of limitations which bring the studies' findings into question. These shortcomings relate most notably to the limited financial outcomes, truncated observation period, and narrow sets of determinants. First, early studies treat companies experiencing different post-IPO outcomes as a homogenous group. They do not distinguish the companies acquired due to favourable as opposed to unfavourable reasons (e.g., Chi et al., 2010; Jain \& Kini, 1994; 1999). Companies, 
however, are likely to get acquired prior to a period of either strong or weak performance. These studies can potentially lead to an inaccurate inference with respect to identification and explanation of the company's post-IPO status. Second, earlier studies have little consideration of dynamic evolution of the company over its life cycle, which limits the perspective of each developing stage of the company (Bai et al., 2002; Fan et al., 2007). They treat the status of the company as fixed rather than evolving. Third, the company evolves to a definite state not on a random basis, but on the basis of both the issuer's perspective, such as the issuer's financial performance and industry features, and the investor's perspective, such as corporate ownership and governance. Earlier studies have overlooked some, if not all, of these perspectives that arguably contribute to the differences in the companies' evolution in their aftermarket.

The purpose of this study is to fill this gap in the literature by identifying the extent to which the company's post-IPO outcome varies, along with the determinants of the post-IPO outcomes. We address these issues from three perspectives. First, we extend previous studies of the post-IPO market and operational performance to three distinct post-IPO outcomes, namely, delisting, acquisition due to strong performance, and acquisition due to weak performance. Second, to examine the dynamic corporate evolution, we adopt Cox proportional hazards model which utilizes information available prior to, at and post to the IPO to predict the probability of subsequent transition to one of these three post-IPO states. Third, we track down the effects of a set of variables representing both issuer's and investor' perspectives on the company's trajectory following the IPO. Specifically we examine the impacts of factors representing the issuer's perspectives, such as firm traits, financial indicators and industry structure, and analyze the relative importance of these factors in underpinning the three post-IPO outcomes. Given the unique feature of market operations in China, we also incorporate the investor's perspectives represented by corporate ownership and governance mechanism into survival functions. This new addition allows us to assess to what extent the investor's perspectives are attributed to corporate evolution, in particular in a market where the investor's interests are knowingly largely ignored.

Our contribution to the literature consists firstly in presenting understanding of the impacts of a range of the variables concerning pre-IPO characteristics, offering characteristics, financial indicators, company specifics, industry features, and corporate ownership and governance, 
which appear to act so as to distinguish the outcomes of IPOs. Specifically, carrying out this examination by reference to an important emerging market, our study adds significant evidence for emerging markets to the IPO literature, and sheds light on the importance of institutional infrastructure and functions in shaping the company's post-IPO trajectories. Secondly, we adopt a dynamic approach by way of Cox hazard proportional model to examine the corporate evolution following the IPO using the full firm-year observations for each company. In practical terms, our findings can inform public policy decisions relating to institutional infrastructure and functions as well as pointing to possible effects of ownership and corporate governance decisions connected with planning and shaping a company's postIPO outcome.

The remainder of the paper is organized as follows. Section 2 discusses methodological issues, and develops research questions. Section 3 presents empirical findings and discussions. Section 4 concludes with policy recommendations.

\section{Methodological issues}

\subsection{Sample description and constructing firm groups}

We construct a sample of IPOs on China's stock market for the period of 1998-2008. We extract our sample from the GTA database ${ }^{1}$. All the non-financial companies, including both A-shares and B-shares, are included in this study. The companies are of different sizes and are distributed across 12 types of industry.

We examine three post-IPO outcomes: delisting, acquisition due to strong performance, and acquisition due to weak performance. Based on the three outcomes, we classify companies into three groups: independent companies, delisted companies, and M\&A companies. Independent companies refer to those that have not experienced any of these outcomes until 2008 when the data is censored, and they will be used as the control group in this study. Delisted companies refer to those whose listing has been terminated on the stock exchange

1. The data source of this study are gained from Shenzhen GTA Information Technology Co., Ltd, including China Special Treatment and Particular Transfer Share Research Database (CSMAR-STPT), CSMAR China Stock Market Financial Database (Annual Report), China Corporate Governance Research Database, CSMAR China Stock Market Trading Database, China Stock Market Initial Public Offering Research Database, and China Listed Companies Merger \& Acquisition, Asset Restructuring Research Database. 
due to negative reasons. M\&A companies refer to those whose 50 percent of shares or above $\mathrm{e}^{2}$ are acquired by an existing listed public company or a private company. A listed company can become an acquisition target before a period of either strong or weak performance. We further classify M\&A companies into two sub-groups - companies that have been acquired due to strong performance prior to acquisition (S-M\&A) and companies that have been acquired due to weak performance prior to acquisition (W-M\&A). An M\&A company is defined as $\mathrm{W}-\mathrm{M} \& \mathrm{~A}$ if it meets the following criterion: the return on assets of the company decreases for three consecutive years prior to the acquisition. Any other companies in the M\&A group are defined as S-W\&A. The observation time period comprises three years before the company goes public until the year when one of the outcomes occurs or the closing year of this study, whichever is earlier.

The final sample consists of 1,499 independent companies, 63 delisted companies, and $56 \mathrm{~S}-$ M\&A companies, and $132 \mathrm{~W}-\mathrm{M} \& \mathrm{~A}$ companies for the analysis, with 19,250 evaluable firmyear observations for the study period from 1998 to 2008 .

\subsection{Variables selection and research question}

We include six sets of variables concerning pre-IPO characteristics, offering characteristics, financial indicators, company specifics, industry features, and corporate ownership and governance in predicting the trajectories following the IPO. Specifically, pre-IPO characteristics include operating return on assets and operating cash flow over assets prior to the IPO. Characteristics specific to issuance include IPO offering size, IPO risk, and IPO initial return. Financial indicators include return on assets, current ratio, leverage ratio, and book-to-market ratio. Firm-specific characteristic variables include company size, company age and agency costs. Variables representing industry features include high-technological activities and industry sector in which the company operates. Industry sector is further divided into four sub-sectors: Utilities, Properties, Industrials, and Commerce. Corporate ownership and governance variables include ultimate state ownership, board size, CEO/chairman duality, and board independence. Table 1 summarizes the categories and their associated variables including the definitions.

2. According to Article 84 of the "Administration Measures on Takeover of Listed Companies", approved at the 180th Chairman's Meeting of the CSRC on May 17, 2006, an investor has controlling right of a listed company if being the controlling shareholder of the acquired listed company with over $50 \%$ of its shares. 
Our range of variables sets out to distinguish the antecedents of the situation from its intrinsic characteristics at the time of the IPO; also to distinguish the overall corporate dimension from characteristics of the issue itself; and finally to cover a set of variables which focuses on the investor's perspective. This set-up leads us to the following formal research questions: is it possible to identify the relative influence exerted by specified issue, issuer, corporate, financial, ownership and governance, and contextual factors on the occurrence of specified outcomes following an IPO? What factors most powerfully determinate the company's postIPO outcome in its aftermarket?

[Insert Table 1 here]

\subsection{Empirical specifications}

Unlike logistic models which assume that the underlying failure process remains fixed over time, survival analysis pertains to a statistical approach designed to take into account the time between entry into observation and a subsequent event and captures dynamic trajectories in the real world. Events estimated by survival analysis are defined by a transition from one discrete state to another at a consecutive moment. A popular model used in survival analysis is Cox Proportional Hazard Model which assesses the importance of time-varying covariates in the survival times of each individual company through the hazard function. The advantage of this approach is that it accepts censored data as far as a failure event is concerned, and allows estimates of failures over any future time horizon (Kleinbaum and Klein, 2005). Thus, Cox model incorporates time-varying covariates or explanatory variables that change with time (Liu et al., 2013).

In this study, we adopt the Cox hazard model to examine the probability of the company's transitioning to one of the post-IPO states, namely delisting, acquisition due to strong performance, and acquisition due to weak performance. The Cox hazard analysis utilizes the coefficients of explanatory variables to estimate the probability of outcome occurrence and to derive predicted hazard functions for testing the hypothesized relations between the probability of outcome occurrence and the set of explanatory variables. The hypothesized relation between the post-IPO outcomes and the explanatory variables are expressed below:

$\operatorname{Cox}\left(\mathrm{S}-\mathrm{M} \& \mathrm{~A}_{\mathrm{it}}=1 \mid X_{\mathrm{it}}\right)=\beta_{11} \mathrm{OPRA}_{\mathrm{it}}+\beta_{12} \mathrm{OCFA}_{\mathrm{it}}+\beta_{13}$ OFFSIZE $_{\mathrm{it}}+\beta_{14} \mathrm{RISK}_{\mathrm{it}}+\beta_{15}$ RETURN $_{\mathrm{it}}+$ $\beta_{16} \mathrm{ROA}_{\text {it }}+\beta_{17} \mathrm{CUR}_{\mathrm{it}}+\beta_{18} \mathrm{LEV}_{\mathrm{it}}+\beta_{19} \mathrm{~B} / \mathrm{M}_{\mathrm{it}}+\beta_{110} \mathrm{SIZE}_{\mathrm{it}}+\beta_{111} \mathrm{AGE}_{\mathrm{it}}+\beta_{112} \mathrm{AGEN}_{\mathrm{it}}+\beta_{113} \mathrm{INDUS}_{\mathrm{it}}+$ 
$\beta_{114} \mathrm{TECH}_{\mathrm{it}}+\beta_{115} \mathrm{ULTI}_{\mathrm{it}}+\beta_{116} \mathrm{DUAL}_{\mathrm{it}}+\beta_{117} \mathrm{BOARD}_{\mathrm{it}}+\beta_{118} \mathrm{INDEP}_{\mathrm{it}}$

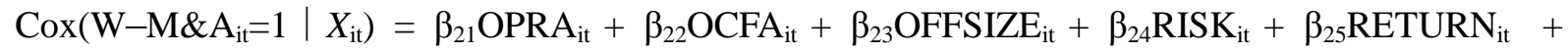
$\beta_{26} \mathrm{ROA}_{\mathrm{it}}+\beta_{27} \mathrm{CUR}_{\mathrm{it}}+\beta_{28} \mathrm{LEV}_{\mathrm{it}}+\beta_{29} \mathrm{~B} / \mathrm{M}_{\mathrm{it}}+\beta_{210} \mathrm{SIZE}_{\mathrm{it}}+\beta_{211} \mathrm{AGE}_{\mathrm{it}}+\beta_{212} \mathrm{AGEN}_{\mathrm{it}}+\beta_{213} \mathrm{INDUS}_{\mathrm{it}}+$ $\beta_{214} \mathrm{TECH}_{\text {it }}+\beta_{215} \mathrm{ULTI}_{\mathrm{it}}+\beta_{216} \mathrm{DUAL}_{\mathrm{it}}+\beta_{217} \mathrm{BOARD}_{\mathrm{it}}+\beta_{218} \mathrm{INDEP}_{\text {it }}$

$\operatorname{Cox}\left(\right.$ Delisted $\left._{\mathrm{it}}=1 \mid X_{\mathrm{it}}\right)=\beta_{31} \mathrm{OPRA}_{\mathrm{it}}+\beta_{32} \mathrm{OCFA}_{\mathrm{it}}+\beta_{33}$ OFFSIZE $_{\mathrm{it}}+\beta_{34}$ RISK $_{\mathrm{it}}+\beta_{35}$ RETURN $_{\mathrm{it}}+$ $\beta_{36} \mathrm{ROA}_{\mathrm{it}}+\beta_{37} \mathrm{CUR}_{\mathrm{it}}+\beta_{38} \mathrm{LEV}_{\mathrm{it}}+\beta_{39} \mathrm{~B} / \mathrm{M}_{\mathrm{it}}+\beta_{310} \mathrm{SIZE}_{\mathrm{it}}+\beta_{311} \mathrm{AGE}_{\mathrm{it}}+\beta_{312} \mathrm{AGEN}_{\mathrm{it}}+\beta_{313} \mathrm{INDUS}_{\mathrm{it}}+$ $\beta_{314} \mathrm{TECH}_{\mathrm{it}}+\beta_{315} \mathrm{ULTI}_{\mathrm{it}}+\beta_{316} \mathrm{DUAL}_{\mathrm{it}}+\beta_{317} \mathrm{BOARD}_{\mathrm{it}}+\beta_{318} \mathrm{INDEP}_{\mathrm{it}}$

where $\mathrm{S}-\mathrm{M} \& \mathrm{~A}_{\mathrm{it}}$ represents the status of being acquired due to strong performance; $\mathrm{W}-\mathrm{M} \& \mathrm{~A}_{\mathrm{it}}$

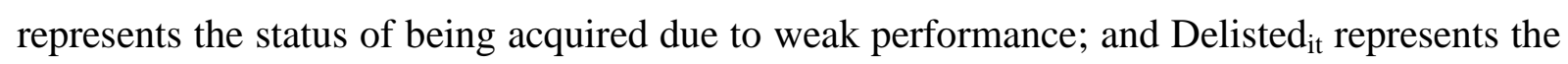
status of being delisting. $\mathrm{S}-\mathrm{M} \& \mathrm{~A}_{\mathrm{it}}, \mathrm{W}-\mathrm{M} \& \mathrm{~A}_{\mathrm{it}}$ and Delisted $_{\mathrm{it}}$ are the dependent dummy variable in Equation 1, Equation 2 and Equation 3, respectively. $X_{\mathrm{it}}$ is a vector of the covariates to be estimated for company $i$ in year $t . \quad \beta$ is a vector of the regression coefficients.

Hazard ratio $(H R)$ has a positive value. A negative coefficient, i.e., $H R<1$, indicates that the explanatory variable increases the probability of outcome occurrence. A positive coefficient, $H R>1$, suggests that the explanatory variable accelerates outcome occurrence and increases the company's probability of transitioning to one of the post-IPO states. When the estimated $H R$ is unity, i.e., $H R=1$, the company's post-IPO state is unresponsive to the specific explanatory variable.

\subsection{Basic statistics}

Table 2 reports mean and median values of the explanatory variables for the three post-IPO outcomes and the results of pairwise comparisons between these outcomes. We employ the Wilcoxon-Mann-Whitney Test to examine whether there are differences in distributions between the three groups of companies. Several significant differences between each pairs of groups stand out.

Prior to the IPO, companies with the delisting status display the lowest performance profile at the $1 \%$ level. In comparison, companies with the S-M\&A status are highest in pre-IPO operating performance at the $10 \%$ level. The initial results suggest that lower pre-IPO performance may lend companies to an increased risk of subsequent delisting in their aftermarket, while companies with strong operating performance prior to the IPO may encounter a higher likelihood of getting acquired. 
With respect to offering characteristics, S-M\&A companies have the largest offering size among the three groups, while the opposite holds for delisted companies. These suggest that a larger offering reduces the chance of survival. Companies with large amounts of free cash flow at managerial discretion have potentially greater agency costs of equity, as managers can use the cash in ways that may reduce shareholders' value. Further, S-M\&A companies display the lowest level of risk, indicating that S-M\&A companies with lower risk are less likely to lend themselves to being acquired. IPO initial returns are predictably higher for delisted companies than for the other two M\&A groups, while S-M\&A companies tend to have lower initial returns than $\mathrm{W}-\mathrm{M} \& \mathrm{~A}$ companies. Higher initial returns may be an indication of significant uncertainty and severe informational asymmetries inherent within the companies concerned. These observed differences suggest that IPO initial returns could be a predictor for future risk of delisting.

There are significant differences in the company's performance and financial status prior to the occurrence of the eventual outcomes. S-M\&A companies are significantly higher in return on assets, current ratios and book-to-market ratio, but lower in leverage ratio compared to delisted companies. Delisted companies display the lowest level of book-tomarket ratio among the three groups. This may suggest the possibility that low B/M ratio may be influenced by potentially unfavourable factors such as the existence of intangible assets prone to overvaluation or overvalued growth itself.

Turning to company specifics, there is no significant difference in company size among the three groups. However, W-M\&A companies tend to have longer history than S-M\&A companies, while delisted companies have the longest history among the three groups. One possible explanation is that very few companies survive over time because company performance decreases with company age and that it does so at a diminishing rate. In terms of agency costs, there appears to be no significant discrepancy in agency costs among the three groups. Further, $15.91 \%$ of $\mathrm{W}-\mathrm{M} \& \mathrm{~A}$ companies, $10.71 \%$ of $\mathrm{S}-\mathrm{M} \& \mathrm{~A}$ companies and $6.35 \%$ of delisted companies engage in high-tech activities.

Concerning corporate ownership, distinctive patterns emerge. $78.49 \%$ of S-M\&A companies are ultimately owned by the state compared to $76.07 \%$ for $\mathrm{W}-\mathrm{M} \& \mathrm{~A}$ companies and $48.96 \%$ for delisted companies. These are clear evidence to indicate that ultimately state ownership dominates in Chinese listed companies. It is also noted that companies with higher presence 
of state ownership are more likely to encounter acquisition than delisting. Such an indication coincides with the recent stock-split reform where state-owned companies have been undergoing significant asset restructuring by way of mergers and acquisitions.

With respect to corporate governance attributes, it appears that board size in delisted companies (9.84) is higher compared to S-M\&A companies (9.44) and W-M\&A companies (9.36). CEO/Chairman duality is $16.58 \%$ in delisted companies, $14.39 \%$ in S-M\&A companies, and $13.46 \%$ in $\mathrm{W}-\mathrm{M} \& \mathrm{~A}$ companies. There is, however, no significant difference in $\mathrm{CEO} /$ chairman duality across these groups. Further, delisted companies have the lowest level of board independence (13.92\%), while it is $22.16 \%$ for $\mathrm{W}-\mathrm{M} \& \mathrm{~A}$ companies and $23.56 \%$ for S-M\&A companies. The observed differences are suggestive of a potential role of board independence in shaping the company's post-IPO outcome. In spite of the differences, listed companies in China, in general, have a low level of board independence.

Overall, these results suggest a link between the company's post-IPO outcomes and the characteristics of the issuer and the issue itself, as well as the antecedents and their intrinsic characteristics spanning corporate dimension. To avoid muticollinearity of the variables in the estimation, we conducted correlation coefficient analysis ${ }^{3}$. The results show that multicollinearity is not a concern for the selected variables in our study, since all the correlation coefficients are below $|0.80|$. We will accordingly test the validity of the abovediscussed observations using Cox hazard model in the analyses that follow.

[Insert Table 2 here.]

\section{Empirical results}

We present three sets of the empirical results of the Cox regression analysis in Table 3. SM\&A outcome in Panel A, W-M\&A outcome in Panel B, and delisting outcome in Panel C. Within each panel, Model 1 presents the basic model without corporate governance attributes and industry sector. Model 2 presents results that consider corporate governance attributes including CEO duality, board size and board independence. Model 3 presents results that consider corporate governance attributes and industry sector. We identify some distinct patterns across the three post-IPO outcomes.

3. The descriptive statistics for these variables along with the correlation coefficients are available upon request. 
[Insert Table 3 here]

Pre-IPO Characteristics. Panel A of Table 3 shows that there is a positive relation between operating return/assets (OPRA) and the likelihood of the S-M\&A status at the 10\% level. By contrast, Panel $\mathrm{C}$ shows that OPRA has a significant, negative impact on the likelihood of delisting (Model 1: 0.05; Model 2: 0.06; Model 3: 0.05, $\mathrm{p}<0.01$ ). This is clear evidence to indicate that higher pre-IPO operating performance signifies companies' ability to survive successfully in their aftermarket, and hence subjects companies to a less likelihood of delisting. However, there is no evidence to suggest that operating cash flow over/assets has an impact on the post-IPO outcome, though correctly signed. This indicates that this financial measurement does not constitute a good predictor for the company's future performance. Overall, our results are broadly consistent with the findings of Jain and Kini (1999), Peristiani and Hong (2004) and Wang (2004).

Offering Characteristics. There is significant evidence to suggest that large IPO offering size increases the likelihood of transitioning to the S-M\&A status, while the opposite holds for the W-M\&A outcome. The offering size, however, has little impact on the delisting state. Our finding is partly supported by several prior studies that large IPO offering size reduces the probability of being acquired due to weak performance (Ti, 2003; Hovey and Li, 2009).

IPO risk generates a negative impact on the likelihood of acquisition due to strong performance. Further, higher company risk at the time of the IPO increases the likelihood of delisting in Model 1 and Model 3 at the $1 \%$ level, but reduces the likelihood of the S-M\&A outcome (Panel A: Model 2: 0.47) at the 1\% level. These results provide empirical evidence to support the argument that company risk at the time of the IPO accounts for the poor longrun performance (Rao, 1989; Ritter, 1991), and increases the chance of delisting (Palepu, 1986; Jain and Kini, 1999). Our results are consonant with the current China's position that the stock market is increasingly volatile and is plagued with big bubbles, and companies find it particularly hard to remain viable in the volatile market.

There is no evidence to suggest that IPO initial return is associated with the S-M\&A outcome, but that it is positively associated with the likelihood of evolving to the W-M\&A state (Panel B: Model 1: 1.09; Model 2: 1.04; Model 3: 1.11, p<0.01). Further, companies with high initial returns are more likely to be delisted (Panel C: Model 1: 1.33; Model 2: 1.19; Model 3: 
1.14, p <0.01). Our results are consonant with Chi et al.'s (2010) that there is a negative relationship between IPO initial return and company survival. Our findings highlight that volatility in offering price of the first trading day captures uncertainty in the valuation of IPOs. High initial returns to IPOs often lead to excessive demand for IPOs especially in China (Liu, et al., 2013), resulting in high uncertainty and thereby high incidence of delisting.

Financial Indicators. The return on assets ratio (ROA) does not appear to set any effects on the likelihood of M\&A outcomes of both forms in Panel A and Panel B. However, ROA is negatively related to the likelihood of delisting (Panel C: Model 1: 0.80, p<0.01; Model 2: 0.90, $\mathrm{p}<0.00$; Model 3: 0.90, $\mathrm{p}<0.05)$. These are clear evidence to indicate that companies with weak profitability are more likely to be delisted from the stock market. Current ratio generates a positive impact on the likelihood of the S-M\&A outcome at the $10 \%$ level, while the opposite holds for $\mathrm{W}-\mathrm{M} \& \mathrm{~A}$ outcome at the $5 \%$ level. We did not find evidence that current ratio accounts for the company's ability to survive. Leverage ratio has a positive effect on the likelihood of the W-M\&A outcome. This result is contrary to the majority of findings that high leverage tends to deter acquirers. There is no evidence to suggest that leverage has an impact on delisting, though positively signed. The B/M ratio has a significant, negative impact on the likelihood of transitioning to the $\mathrm{W}-\mathrm{M} \& \mathrm{~A}$ state at the $1 \%$ level. One possible explanation is that under-performing companies with low $\mathrm{B} / \mathrm{M}$ may be perceived as overpriced stocks by the market, thus deterring acquirers due to cost considerations. Likewise, the $\mathrm{B} / \mathrm{M}$ ratio produces a negative impact on delisting. This suggests the possibility to the effect that when companies accumulate large losses, book-market ratio may turn into negative; as such, the risk of financial distress increases as the ratio consistently decreases. Our result does not support Fama and French's (1995) proposition that high (low) B/M companies may embody high (low) distress-risk.

Company Specifics. The variables representing firm specifics are found significant. Company size displays a significant, positive relationship with the likelihood of both forms of M\&A outcomes. These results provide evidence to the effect that that large companies, usually SOEs, are undergoing restructuring via asset carve-outs or asset exchange with their parent companies or with potential acquirers as a part of the government's policy for restructuring state-owned enterprises. However, there is no evidence to suggest that company size is associated with the likelihood of delisting. The effects of company age are mixed. Company 
age is negatively associated with delisting, indicating that older companies are more capable to rejuvenate themselves in order to avoid the delisting consequence. Company age, however, has no impact on the likelihood of both forms of M\&A outcomes.

Most notably, the variable representing agency costs has a significant, negative effect on the delisting and W-M\&A outcomes. The significance of free cash flow is more marked for delisted companies (Panel C: Model 2: 3.38, $\mathrm{p}<0.01$; Model 3: 3.00, $\mathrm{p}<0.05$ ) than $\mathrm{W}-\mathrm{M} \& \mathrm{~A}$ companies (Panel B: Model 1: 1.56, $\mathrm{p}<0.10$; Model 3: 1.43, $\mathrm{p}<0.10$ ). These results support the free cash flow hypothesis that when companies generate substantial free cash flows, the conflicts of the interests between managers and shareholders are intensified. Large cash flow induces agency problems by motivating managers to disgorge the cash or wasting it on nonmaximizing activities, hence damaging the company's prospects for survival, or lending the company to an easy takeover target.

Industry features. Industry specifics have distinct effects on the company's post-market viability. High-tech activities have a significant, positive impact on the S-M\&A outcome at the $1 \%$ level, suggesting that better-performing companies with high-tech advantages are more attractive to acquirers relative to non-high technology companies, as such establishments have a potential to enhance acquirers' competitiveness. To the contrary, companies engaging in high-tech activities are less likely to get delisted. These results are consistent with prior studies that innovative conditions at the industry level matters for the continuance of the company (Jain and Kini, 1999; Chi and Padgett, 2002; Demers and Joos, 2006).

Further, our results show that companies in the Utilities sector are less likely to experience delisting (Panel C: Model 3: 0.53, p<0.10). This is evidence to the effect that companies operating in the Utilities sector are monopoly in the market and hence face the least likelihood of delisting. By contrast, companies in the Industrials sector are confronted with a higher risk of delisting (Panel C: Model 3: 2.08, $\mathrm{p}<0.01$ ). With respect to the M\&A outcomes, companies operating in the Properties sector (Panel A: Model 3: 3.35; Panel B: Model 3: 3.38) and the Industrials sector (Panel A: Model 3: 1.64; Panel B: Model 3: 1.98) are most likely to experience both forms of M\&A outcomes at the $1 \%$ level. These are consistent with the recent M\&A moves in China that companies in these two sectors are increasingly engaged in vertical acquisitions targeting at the market share and occupying the dominant market position as 
noted in Liu et al. (2013). Further, we find contrasting effects on the M\&A outcomes for companies operating in the Commerce sector. These companies experience a lower likelihood of transitioning to the S-M\&A status (Panel A: Model 3: 0.33, $\mathrm{p}<0.10$ ) but a higher likelihood of transitioning to the W-M\&A status (Panel B: Model 3: 1.50, $\mathrm{p}<0.10$ ). Companies in the Commerce sector are relatively smaller-scaled and tend to operate in Wholesale, Retail Trade, Media, and Social Services. Under-performing companies in these industries are cheaper to buy and thus attract acquirers.

Corporate Ownership and Governance. Ultimate state ownership evinces instructively contrasting results for the three post-IPO outcomes. Ultimate state ownership generates a positive impact on the S-M\&A outcome (Panel A: Model 1: 1.55; Model 2: 1.53; Model 3: $1.54, \mathrm{p}<0.10 \%)$. Likewise, companies that are ultimately owned by the state are more likely to encounter the risk of experiencing the W-M\&A outcome (Panel B: Model 1: 4.36; Model 2: 4.18; Model 3: 3.38, $\mathrm{p}<0.01 \%$ ). Our results suggest that state-owned companies are more likely to get acquired regardless of the form of M\&As. These findings coincide with the ongoing ownership structure reform, which encourages restructuring state-owned assets by way of asset carve-outs or asset exchange with their parent companies or with potential acquirers. In so far as this is correct, our results are clear suggestion that state ownership is the vital factor in determining the M\&A transactions in China.

By contrast, ultimate state ownership generates a significant, negative effect on delisting (Panel C: Model 1: 0.67; Model 2: 0.44; Model 3: 0.45, $\mathrm{p}<0.01 \%$ ). This is clear evidence to indicate that state-owned companies are less likely to face delisting. Companies where state ownership is predominant often operate in the national strategic industrial sectors. When they are in the perceived risk of being delisted, the government takes measures to protect stateowned property rights by exercising political power to prevent these companies from being driven out of the market. This is consistent with discussions of Bradford et al. (2013) and Liu and Pang (2009) that state shareholders have priority to a greater access to obtain the protection of the government. Large presence of state ownership in listed companies is derived from the economic, culture, political and legal environment of China. Due to corporate control considerations, the government is unlikely to disregard state-owned companies undergoing failures.

There are some mixed effects of corporate governance measures at the time of IPO offerings. 
$\mathrm{CEO} /$ chairman duality is positively related to the likelihood of the $\mathrm{W}-\mathrm{M} \& \mathrm{~A}$ outcome (Model 3: $1.16, \mathrm{p}<0.10 \%$ ), supporting the agency hypothesis that duality compromises the board's effectiveness in monitoring CEOs, leading to a worsening of company performance and hence increasing the chance of acquisition due to poor performance. We find contrasting effects of board size on the post-IPO outcomes. Board size has a negative impact on the likelihood of the S-M\&A outcome (Panel A: Model 2: 0.97, $\mathrm{p}<0.10$ ), but a positive effect on the $\mathrm{W}-\mathrm{M} \& \mathrm{~A}$ outcome (Panel B: Model 2: 1.06, p<0.01; Model 3: 1.04, $\mathrm{p}<0.05)$ and the delisting outcome (Panel C: Model 2: 1.11, $\mathrm{p}<0.01$; Model 3: 1.13, $\mathrm{p}<0.01$ ). This is evidence to the effect that a larger board may be difficult to engage all directors in company affairs effectively so that they are able to candidly contribute to the company, thus increasing the likelihood of transitioning to the $\mathrm{W}-\mathrm{M} \& \mathrm{~A}$ and delisting states.

With respect to board independence, Independent directors are weakly related to the likelihood of the W-M\&A outcome (Panel B: Model 2: 0.01, p<0.10; Model 3: 0.02, $\mathrm{p}<0.10 \%)$. We did not find any significant effect of board independence on other post-IPO outcomes. Against the widely-held expectation for the role of board independence in shareholder value maximization, our result suggests that independent directors are yet to assume the monitoring role which helps align the interests of managers with those of shareholders. Independent directors in mature markets focus more on solving agency problems while independent directors in China aim at protecting self-interests or engage in relation building (Kato and Long, 2006a). In the meantime, many of them find it difficult to exert the significant influence other than figure influence on the company that they serve. These results are of significance as they show that the basic element of independence must be fulfilled before the management consider increasing the proportion of independent directors on the board.

\section{Conclusion}

We examine what determines the company's post-IPO transition to one of the classified outcomes, delisting, acquisition due to strong performance, and acquisition due to weak performance. We develop models taking in a range of information concerning the issuer's perspective and the investor's perspective. We find that the post-IPO trajectories are subject to the varying degrees of determination relating to the company's pre-IPO and offering characteristics, financial indicators, company specifics, industry structure, and corporate 
ownership and governance.

Two key findings emerge. First, delisting is predominantly influenced by the company' preIPO operating performance, as well as financial indicators and governance structure at the time of the IPO. The evidence indicates that profitability and healthy financial status are necessary prerequisites for survival as an independent business entity. Failure to satisfy these criteria means, ultimately, that the company will disappear from the market scene. Sound governance structure and good quality of IPO companies aid the companies to achieve this goal. Second, M\&As of both forms are distinguished most significantly by the company' industry features and ownership structure. Our analyses suggest that industry structure affects efficiency and competition in the outcome. Further, we find significant evidence that ultimate state ownership predominantly determines the M\&A outcomes. This is consonant with the fact that M\&As are majorly motivated by social concerns, protection of the stake of the state in corporate ownership, and corporate control considerations. Centrally, corporate evolution is jointly shaped by market force and state control.

Our study raises some policy issues that merit discussions. The results suggest that the trajectory leading to and following an IPO should not be trammeled so as to constrain economically beneficial decisions. In particular, there is a case for gradual introduction of institutional changes which facilitate, regulate and monitor orderly market exit operations in line with the market mechanism and sound corporate governance. Our study calls for the extension of the review of these aspects to other markets, given the widespread problems of its kind that gave rise to the economic crisis.

We finally submit that our study raises issues for future research. State controls permeate corporate decisions. The market and its institutions are not yet operating in line with the market rules, and controlling shareholders can easily reap private benefits by maintaining their controlling position in the company. Not least can this militate against minority shareholders' interests. Our findings confirm and reinforce the case for developing models of integrating corporate control with investors' value in the aftermath of IPOs. Our work could be pursued into other corporate decisions. For example, research into valuation and financing motives associated with mergers and acquisitions in China could benefit from our findings on the antecedents of M\&As. A further step could be a comparative study with economies with a similar setup and might include the impact of a major change in regulation. 


\section{References}

Ang, J.S., Cole, R.A. and Lin, J.W. (2000), "Agency costs and ownership structure", The Journal of Finance, Vol. 55 No. 1, pp. 81-106.

Baker, M. and Gompers, P.A. (2003), "The determinants of board structure at the Initial Public Offering", Journal of Law and Economics, Vol. 46 No. 2, pp. 569-98.

Bai, C., Liu, Q. and Song, F. M. (2002), "Value of corporate control: evidence from China's distressed firms", working paper, Hong Kong, May.

Bradford, W., Chen, C. and Zhu, S. (2013), "Cash dividend policy, corporate pyramids, and ownership structure: evidence from China", International Review of Economics and Finance, Vol. 27, pp. 445-64.

Campbell, J.Y., Hilscher, J. and Szilagyi, J. (2008), "In search of distress risk", Journal of Finance, Vol. LXIII No. 6, pp. 2899-939.

Chen, G., Firth, M., Gao, D.N. and Rui, O.M. (2006), "Ownership structure, corporate governance, and fraud: evidence from China", Journal of Corporate Finance, Vol. 12, pp. 424-48.

Chi, J., McWha, M. and Young, M. (2010), "The performance and the survivorship of New Zealand IPOs", International Review of Financial Analysis, Vol. 19, pp. 172-80.

Chi, J. and Padgett, C. (2002), "The performance and long-run characteristics of the Chinese IPO market", working paper, University of Reading, Reading, April.

De, S. and Jindra, J. (2012), "Why newly listed firms become acquisition targets", Journal of Banking and Finance, Vol. 36, pp. 2616-31.

Demers, E.A. and Joos, P. (2006), "IPO failure risk", Journal of Accounting Research, Vol. 45 No. 2, pp. 333-71.

Dennis, D.K. and McConnell, J.J. (2003), "International corporate governance", Journal of Financial and Quantitative Analysis, Vol. 38 No. 1, pp. 1-36.

Fama, E.F. and French, K.R. (2004), "New lists and seasoned firms: fundamentals and survival rates", Journal of Financial Economics, Vol. 73, pp. 229-70.

Fan, J.P.H., Huang, J. and Zhu, N. (2007), "Financial distress without bankruptcy: the case of China", working paper, University of California, California, June.

Gilson, S.C. (1989), "Management turnover and financial distress", Journal of Financial Economics, Vol. 25, pp. 241-62.

Goergen, M. (1998), Corporate Governance and Financial Performance - A Study of German and UK Initial Public Offerings, Edward Elgar, Cheltenham, UK.

Guo, H. and Brooks, R. (2009), "Duration of IPOs between offering and listing: Cox Proportional Hazard Models - evidence for Chinese A-share IPOs", Administrative Science Quarterly, Vol. 33, pp. 1-23.

Henning, C.H.C.A and Lu, X. (2000), "The political foundation of Chinese style gradualism: a paradox of too strong private interests", Journal of Institutional and Theoretical Economics, Vol. 156 No. 1, pp. 35-59.

Holmstrom, B. and Kaplan, S.N. (2001), "Corporate governance and merger activity in the United States: making sense of the 1980s and 1990s", Journal of Economic Perspectives, Vol. 15 No. 2, pp. 121-44.

Hovey, M. and Li, L. (2009), "Does IPO underpricing in China explain a firm's long-term performance: an empirical study of IPOs in China with corporate governance perspectives", working paper, RMIT University, Melbourne, January.

Jain, B.A. and Kini, O. (1994), "The post-issue operating performance of IPO firms", Journal of Finance, Vol. 49, pp. 1699-726. 
Jain, B.A. and Kini, O. (1999), "The life cycle of Initial Public Offering firms", Journal of Business \& Accounting, Vol. 26 No. 9\&10, pp. 1281-307.

Jain, B.A. and Kini, O. (2008), "The impact of strategic investment choices on post-issue operating performance and survival of US IPO firms", Journal of Business Finance \& Accounting, Vol. 35 No. 3\&4, pp. 459-90.

Jensen, M.C. and Meckling, W.H. (1976), "Theory of the firm: managerial behavior, agency cost, and ownership structure", Journal of Financial Economics, Vol. 3, pp. 305-60.

Kato, T. and Long, C. (2006a), "Executive compensation, firm performance and corporate governance in China: evidence from firms listed in the Shanghai and Shenzhen Stock Exchanges", Economic Development and Cultural Change, Vol. 54 No. 4, pp. 945-83.

Kleinbaum, D.G. and Klein, M. (2005), Survival Analysis - A Self-Learning Text (2nd Ed.), Springer, New York, NY.

Li, H. and Cui, L. (2003), "Empirical study of capital structure on agency costs in Chinese listed companies", Nature and Science, Vol. 1 No. 1, pp. 12-20.

Liu, J. and Pang, D. (2009), "Financial factors and company investment decisions in transitional China", Managerial and Decision Economics, Vol. 30, pp. 91-108.

Liu, J., Lister, R., and Pang, D. (2012). "Corporate Evolution Following Initial Public Offerings in China: A Life-Course Approach". International Review of Financial Analysis. http://dx.doi.org/10.1016/j.irfa.2012.11.003.

Mikkelson, W. et al. (1997), "Ownership and operating performance of companies that go public”, Journal of Financial Economics, Vol. 44, pp. 281-307.

Palepu, K.G. (1986), "Predicting takeover targets: a methodological and empirical analysis", Journal of Accounting and Economics, Vol. 8, pp. 3-35.

Peel, M.J. and Wilson, N. (1989), "The liquidation/merger alternative: some results for the UK corporate sectors", Managerial and Decision Economics, Vol. 10, pp. 209-20.

Peristiani, S. and Hong, G. (2004), "Pre-IPO financial performance and aftermarket survival", Federal Reserve Bank of New York, Vol. 10 No. 2, pp. 1-7.

Rao, G. (1989), "The relation between stock returns and earnings: a study of newly-public firms", working paper, University of Illinois, Illinois.

Ritter, J.R. (1991), "The long-run performance of Initial Public Offerings", Journal of Finance, Vol. 46 No. 1, pp. 3-27.

Theodossiou, P., Kahya, E., Saidi, R. and Philippatos, G. (1996), "Financial distress and corporate acquisitions: further empirical evidence", Journal of Business and Accounting, Vol. 23 No. 5\&6, pp. 699-719.

Ti, L. (2003), "Investment without risk - an empirical investigation of IPO underpricing in China", The China Project Report, No. 4.

Wang, X. (2004), "Reform of state-owned enterprises and corporate governance in China", working paper, School of Management, Fudan University, Shanghai, China, 2004.

Wang Z. and Deng, X. (2006), "Corporate governance and financial distress: evidence from Chinese listed companies", The Chinese Economy, Vol. 39 No. 5, pp. 5-27.

Wei, Z., Xie, F. and Zhang, S. (2005), "Ownership structure and firm value in China's privatized firms: 1991-2001”, Journal of Financial and Quantitative Analysis, Vol. 40 No. 1, pp. 87-108.

Yermack, D. (1996), "Higher market valuation of companies with small board of directors", Journal of Financial Economics, Vol. 40 No. 3, pp. 185-213.

Zhao, J. (2006), "On the definition of independence of independent director in China", USChina Law Review, Vol. 3 No. 4, pp. 56-8. 
Table 1. Description of variables in the estimations

\section{Description}

\section{Pre-IPO characteristics}

Pre-IPO operating return on assets

Pre-IPO operating cash flow/assets

\section{Offering characteristics}

IPO offering size

IPO risk

IPO initial returns

\section{Financial indicators}

Return on assets

Current ratio

Leverage ratio

Book-to-market ratio

\section{Company specifics}

Company size

Company age

Agency costs

\section{Industry features}

Industrial sectors

High-tech activities

\section{Corporate ownership and governance}

Ultimate ownership

CEO/chairman duality

Board size

Board independence
SIZE

AGE

AGEN

TECH

ULTI

DUAL

BOARD

Net income over total assets

Current assets over current liabilities

Book value of debt divided by book value of equity Book value of equity divided by market capitalization of equity at the financial year-end

Natural logarithm of total assets

The number of the year since incorporation

Free cash flow over total assets. Free cash flow is calculated as cash flows from operations minus capital expenditure.
D1 - Utilities
D2 - Properties
D3 - Industrials
D4 - Commerce

A dummy variable taking the value of 1 if the company is a high-tech company, and 0 otherwise

A dummy variable taking the value of 1 if the ultimate owner is the state, and 0 otherwise.

A dummy variable taking the value of 1 if the chairman and CEO positions are held by the same person, and 0 otherwise

The number of members sitting on the board of directors

INDEP The proportion of independent directors on the board 
Table 2. Descriptive statistics of variables in the estimations

\begin{tabular}{|c|c|c|c|c|c|c|c|}
\hline \multirow{3}{*}{ Variable } & \multirow{3}{*}{$\begin{array}{c}\begin{array}{c}\text { Healthy } \\
\text { Companies }\end{array} \\
\begin{array}{c}\text { Mean } \\
\text { (Median) }\end{array} \\
\end{array}$} & \multicolumn{2}{|c|}{ M\&A Companies } & \multirow{2}{*}{$\begin{array}{c}\text { Delisted } \\
\text { Companies }\end{array}$} & \multirow{2}{*}{$\begin{array}{c}\text { Healthy } \\
\text { vs } \\
\text { S-M\&A } \\
\end{array}$} & \multirow{2}{*}{$\begin{array}{c}\text { Healthy } \\
\text { vs } \\
\text { W-M\&A }\end{array}$} & \multirow{2}{*}{$\begin{array}{c}\text { Healthy } \\
\text { vs } \\
\text { Delisted }\end{array}$} \\
\hline & & S-M\&A & W-M\&A & & & & \\
\hline & & $\begin{array}{c}\text { Mean } \\
\text { (Median) }\end{array}$ & $\begin{array}{c}\text { Mean } \\
\text { (Median) }\end{array}$ & $\begin{array}{c}\text { Mean } \\
\text { (Median) }\end{array}$ & Wilcoxon $z$ & Wilcoxon $z$ & Wilcoxon $z$ \\
\hline OPRA & $\begin{array}{c}0.1229 \\
(0.1074)\end{array}$ & $\begin{array}{c}0.1288 \\
(0.1167)\end{array}$ & $\begin{array}{c}0.5891 \\
(0.1207)\end{array}$ & $\begin{array}{c}0.1039 \\
(0.0872)\end{array}$ & $-1.885^{*}$ & $-5.205 * * *$ & $5.413 * * *$ \\
\hline OCFA & $\begin{array}{c}0.1079 \\
(0.1002)\end{array}$ & $\begin{array}{c}0.1167 \\
(0.1318)\end{array}$ & $\begin{array}{c}0.1389 \\
(0.1419)\end{array}$ & $\begin{array}{c}0.0470 \\
(0.0470)\end{array}$ & -0.678 & $-4.141 * * *$ & $2.316^{* *}$ \\
\hline OFFSIZE & $\begin{array}{c}17.4362 \\
(17.5000)\end{array}$ & $\begin{array}{c}17.5600 \\
(17.5000)\end{array}$ & $\begin{array}{c}17.2852 \\
(17.3700)\end{array}$ & $\begin{array}{c}17.2139 \\
(17.2200)\end{array}$ & -0.280 & $5.430 * * *$ & $7.232 * * *$ \\
\hline RISK & $\begin{array}{c}0.4634 \\
(0.2068)\end{array}$ & $\begin{array}{c}0.3678 \\
(0.2588)\end{array}$ & $\begin{array}{c}0.4825 \\
(0.2383)\end{array}$ & $\begin{array}{c}0.6126 \\
(0.2729)\end{array}$ & $-4.248 * * *$ & $-6.925 * * *$ & $-5.615 * * *$ \\
\hline RETURN & $\begin{array}{c}2.2666 \\
(1.1636)\end{array}$ & $\begin{array}{c}2.0609 \\
(1.4500)\end{array}$ & $\begin{array}{c}2.9747 \\
(1.2955)\end{array}$ & $\begin{array}{c}3.7750 \\
(1.7534)\end{array}$ & $-3.313 * * *$ & $-7.137 * * *$ & $-8.305^{* * *}$ \\
\hline ROA & $\begin{array}{l}-0.0960 \\
(0.0333)\end{array}$ & $\begin{array}{c}0.0353 \\
(0.0422)\end{array}$ & $\begin{array}{c}0.0105 \\
(0.0306)\end{array}$ & $\begin{array}{l}-0.3109 \\
(0.0149)\end{array}$ & $-4.264 * * *$ & $2.851 * * *$ & $7.011 * * *$ \\
\hline CUR & $\begin{array}{c}1.6643 \\
(1.2733)\end{array}$ & $\begin{array}{c}1.6704 \\
(1.3839)\end{array}$ & $\begin{array}{c}1.6771 \\
(1.3200)\end{array}$ & $\begin{array}{c}1.3370 \\
(1.0673)\end{array}$ & $-2.332 * *$ & $-1.700 *$ & $7.764 * * *$ \\
\hline LEV & $\begin{array}{c}0.6806 \\
(0.3996)\end{array}$ & $\begin{array}{c}0.5470 \\
(0.3298)\end{array}$ & $\begin{array}{c}0.6578 \\
(0.4050)\end{array}$ & $\begin{array}{c}0.6717 \\
(0.3636)\end{array}$ & $2.496^{* *}$ & -1.509 & 0.976 \\
\hline $\mathrm{B} / \mathrm{M}$ & $\begin{array}{c}0.7260 \\
(0.3717)\end{array}$ & $\begin{array}{c}0.3905 \\
(0.3306)\end{array}$ & $\begin{array}{c}0.3709 \\
(0.3022)\end{array}$ & $\begin{array}{c}0.0943 \\
(0.2080)\end{array}$ & $4.191 * * *$ & $8.020 * * *$ & $13.684 * * *$ \\
\hline SIZE & $\begin{array}{c}21.1454 \\
(21.0451)\end{array}$ & $\begin{array}{c}21.3767 \\
(21.3165)\end{array}$ & $\begin{array}{c}21.2004 \\
(21.0933)\end{array}$ & $\begin{array}{c}20.8690 \\
(20.8147)\end{array}$ & $-4.999 * * *$ & $-2.597 * * *$ & $4.390 * * *$ \\
\hline AGE & $\begin{array}{c}7.0474 \\
(7.0000)\end{array}$ & $\begin{array}{c}8.1607 \\
(8.0000)\end{array}$ & $\begin{array}{c}8.7879 \\
(8.0000)\end{array}$ & $\begin{array}{c}10.4127 \\
(10.0000)\end{array}$ & $-4.455 * * *$ & $-10.603 * * *$ & $-16.003 * * *$ \\
\hline AGEN & $\begin{array}{c}-0.0121 \\
(-0.0076)\end{array}$ & $\begin{array}{c}-0.0088 \\
(-0.0032)\end{array}$ & $\begin{array}{c}-0.0128 \\
(-0.0062)\end{array}$ & $\begin{array}{c}-0.0241 \\
(-0.0084)\end{array}$ & -1.604 & -1.060 & 1.022 \\
\hline TECH (\%) & $\begin{array}{c}14.54 \\
(0.0000)\end{array}$ & $\begin{array}{c}10.71 \\
(0.0000)\end{array}$ & $\begin{array}{c}15.91 \\
(0.0000)\end{array}$ & $\begin{array}{c}6.35 \\
(0.0000)\end{array}$ & $2.657 * * *$ & -1.411 & $6.051 * * *$ \\
\hline ULTI (\%) & $\begin{array}{c}63.51 \\
(100.0000)\end{array}$ & $\begin{array}{c}78.49 \\
(100.0000)\end{array}$ & $\begin{array}{c}76.07 \\
(100.0000)\end{array}$ & $\begin{array}{c}48.96 \\
(0.0000)\end{array}$ & $-7.210 * * *$ & $-9.231 * * *$ & $5.811 * * *$ \\
\hline DUAL (\%) & $\begin{array}{c}14.44 \\
(0.0000)\end{array}$ & $\begin{array}{c}14.39 \\
(0.0000)\end{array}$ & $\begin{array}{c}13.46 \\
(0.0000)\end{array}$ & $\begin{array}{c}16.58 \\
(0.0000)\end{array}$ & 0.032 & 0.976 & -1.155 \\
\hline BOARD & $\begin{array}{c}9.5059 \\
(9.0000)\end{array}$ & $\begin{array}{c}9.4417 \\
(9.0000)\end{array}$ & $\begin{array}{c}9.3563 \\
(9.0000)\end{array}$ & $\begin{array}{c}9.8413 \\
(9.0000)\end{array}$ & $2.014 * *$ & $2.887 * * *$ & $-2.451 * *$ \\
\hline INDEP (\%) & $\begin{array}{c}24.97 \\
(33.33)\end{array}$ & $\begin{array}{c}23.56 \\
(33.33)\end{array}$ & $\begin{array}{c}22.16 \\
(33.33)\end{array}$ & $\begin{array}{c}13.92 \\
(0.0000)\end{array}$ & 1.543 & $7.144 * * *$ & $12.520 * * *$ \\
\hline
\end{tabular}

$*(* *, * * *)$ denotes rejection of the null hypothesis at the $10 \%(5 \%, 1 \%)$ significance level.

Variable definitions are given in Table 1. 
Table 3. Cox regression results of three post-IPO outcomes: delisting, S-M\&A, and W-M\&A

\begin{tabular}{|c|c|c|c|c|c|c|c|c|c|}
\hline \multirow{2}{*}{$\begin{array}{c}\text { Explanatory } \\
\text { Variables }\end{array}$} & \multicolumn{3}{|c|}{ Panel A: Dependent Variable - $\operatorname{Cox}\left(\mathrm{S}-\mathrm{M} \& \mathrm{~A}_{\mathrm{it}}=1 \mid X_{\mathrm{it}}\right)$} & \multicolumn{3}{|c|}{ Panel B: Dependent Variable - $\operatorname{Cox}\left(\mathrm{W}-\mathrm{M} \& \mathrm{~A}_{\mathrm{it}}=1 \mid X_{\mathrm{it}}\right)$} & \multicolumn{3}{|c|}{ Panel C: Dependent Variable - $\operatorname{Cox}\left(\right.$ Delisted $\left._{\mathrm{it}}=1 \mid X_{\mathrm{it}}\right)$} \\
\hline & Model 1 & Model 2 & Model 3 & Model 1 & Model 2 & Model 3 & Model 1 & Model 2 & Model 3 \\
\hline OPRA & $\begin{array}{l}0.0132 \\
(-1.35)\end{array}$ & $\begin{array}{c}2.7098^{*} \\
(1.53)\end{array}$ & $\begin{array}{l}0.0297 \\
(-1.09)\end{array}$ & $\begin{array}{l}7.0180 \\
(0.75)\end{array}$ & $\begin{array}{l}7.1465 \\
(074)\end{array}$ & $\begin{array}{l}7.2726 \\
(079)\end{array}$ & $\begin{array}{l}0.0502 * * * \\
(-287)\end{array}$ & $\begin{array}{l}0.0646^{* * * *} \\
(-267)\end{array}$ & $\begin{array}{c}0.0499^{* * * *} \\
(-2.74)\end{array}$ \\
\hline OCFA & 7.3560 & 7.4733 & 5.6623 & 5.2062 & 4.7246 & 2.4814 & 0.000589 & 0.0005084 & 0.0005483 \\
\hline ОСFА & (1.14) & $(1.11)$ & $(0.95)$ & $(0.94)$ & $(0.88)$ & $(0.46)$ & $(-0.97)$ & $(-1.00)$ & $(-0.99)$ \\
\hline OFFSIZE & $\begin{array}{l}0.9317 \\
(-0.42)\end{array}$ & $\begin{array}{l}0.8521 \\
(-0.82)\end{array}$ & $\begin{array}{l}1.0748^{*} \\
(1.58)\end{array}$ & $\begin{array}{c}0.8491 * * * \\
(-370)\end{array}$ & $\begin{array}{c}0.4063 * * * \\
(-2.93)\end{array}$ & $\begin{array}{c}0.4707 * * \\
(-2.39)\end{array}$ & $\begin{array}{l}1.0277 \\
(0.24)\end{array}$ & $\begin{array}{l}1.0488 \\
(0.42)\end{array}$ & $\begin{array}{l}1.4019 \\
(0.66)\end{array}$ \\
\hline RISK & $\begin{array}{l}0.7023 \\
(-0.47)\end{array}$ & $\begin{array}{c}0.4731 * * * * \\
(-3.24)\end{array}$ & $\begin{array}{l}0.9478 \\
(-0.50)\end{array}$ & $\begin{array}{l}1.0039 \\
(0.35)\end{array}$ & $\begin{array}{l}1.0178 \\
(0.38)\end{array}$ & $\begin{array}{l}2.1177 \\
(0.76)\end{array}$ & $\begin{array}{c}1.4495 * * * * \\
(5.95)\end{array}$ & $\begin{array}{l}1.0931 \\
(1.24)\end{array}$ & $\begin{array}{l}1.4835 * * * * \\
(6.11)\end{array}$ \\
\hline RETURN & $\begin{array}{r}1.0053 \\
(0.41)\end{array}$ & $\begin{array}{l}1.0148 \\
(0.45)\end{array}$ & $\begin{array}{l}1.0362 \\
(1.47)\end{array}$ & $\begin{array}{c}1.0866 * * * * \\
(7.04)\end{array}$ & $\begin{array}{c}1.0353^{* * * *} \\
(6.18)\end{array}$ & $\begin{array}{c}1.1110 * * * \\
(8.85)\end{array}$ & $\begin{array}{c}1.3262 * * * * \\
(8.21)\end{array}$ & $\begin{array}{l}1.1904 * * * \\
(5.17)\end{array}$ & $\begin{array}{c}1.1434 * * * * \\
(4.09)\end{array}$ \\
\hline ROA & $\begin{array}{l}(0.41) \\
1.0050 \\
(0.59)\end{array}$ & $\begin{array}{l}1.45420 \\
(0.35)\end{array}$ & $\begin{array}{l}1.0049 \\
(0.75)\end{array}$ & $\begin{array}{l}0.9989 \\
(-0.08)\end{array}$ & $\begin{array}{l}0.9544 \\
(-0.25)\end{array}$ & $\begin{array}{l}0.9835 \\
(-0.09)\end{array}$ & $\begin{array}{c}0.8013^{* * * *} \\
(-5.39)\end{array}$ & $\begin{array}{c}0.8964 * * \\
(-2.51)\end{array}$ & $\begin{array}{c}0.9033^{*} * \\
(-2.33)\end{array}$ \\
\hline CUR & $\begin{array}{c}1.0225^{*} \\
(1.39)\end{array}$ & $\begin{array}{l}1.0031 \\
(0.15)\end{array}$ & $\begin{array}{l}1.0183 \\
(1.06)\end{array}$ & $\begin{array}{c}0.7360^{* * *} \\
(-2.18)\end{array}$ & $\begin{array}{c}0.6633^{* *} \\
(-2.35)\end{array}$ & $\begin{array}{l}0.9957 \\
(-0.24)\end{array}$ & $\begin{array}{l}0.9851 \\
(-0.36)\end{array}$ & $\begin{array}{l}0.9816 \\
(-0.40)\end{array}$ & $\begin{array}{l}0.9742 \\
(-0.55)\end{array}$ \\
\hline LEV & $\begin{array}{l}0.9988 \\
(-0.17)\end{array}$ & $\begin{array}{l}0.9961 \\
(-0.33)\end{array}$ & $\begin{array}{l}0.9974 \\
(-0.02)\end{array}$ & $\begin{array}{c}1.1287^{* * *} \\
(2.38)\end{array}$ & $\begin{array}{c}1.0151^{*} \\
(1.49)\end{array}$ & $\begin{array}{l}1.0160^{*} \\
(1.31)\end{array}$ & $\begin{array}{l}1.0125 \\
(0.55)\end{array}$ & $\begin{array}{l}1.0133 \\
(0.50)\end{array}$ & $\begin{array}{l}1.0136 \\
(0.52)\end{array}$ \\
\hline $\mathrm{B} / \mathrm{M}$ & $\begin{array}{l}0.7620 \\
(-0.45)\end{array}$ & $\begin{array}{l}0.6624 \\
(-0.69)\end{array}$ & $\begin{array}{l}0.5960 \\
(-0.90)\end{array}$ & $\begin{array}{c}0.8049 * * * * \\
(-4.26)\end{array}$ & $\begin{array}{c}0.8311 * * * \\
(-3.69)\end{array}$ & $\begin{array}{c}0.6423 * * * * \\
(-4.94)\end{array}$ & $\begin{array}{c}0.5395 * * * \\
(-8.28)\end{array}$ & $\begin{array}{c}0.5161 * * * \\
(-9.16)\end{array}$ & $\begin{array}{c}0.5176^{* * * *} \\
(-9.33)\end{array}$ \\
\hline SIZE & $\begin{array}{c}1.4691^{*} \\
(1.84)\end{array}$ & $\begin{array}{l}1.2331 \\
(0.90)\end{array}$ & $\begin{array}{c}1.1003^{* *} \\
(2.00)\end{array}$ & $\begin{array}{l}1.7456^{* * *} \\
(2.46)\end{array}$ & $\begin{array}{l}1.2294 * * \\
(2.06)\end{array}$ & $\begin{array}{c}1.8678^{* * * *} \\
(3.05)\end{array}$ & $\begin{array}{l}0.9853 \\
(-0.17)\end{array}$ & $\begin{array}{l}0.9976 \\
(-0.03)\end{array}$ & $\begin{array}{l}0.9462 \\
(-0.63)\end{array}$ \\
\hline AGE & $\begin{array}{l}0.9340 \\
(-1.45)\end{array}$ & $\begin{array}{l}0.9259 \\
(-1.56)\end{array}$ & $\begin{array}{l}0.9463 \\
(-1.26)\end{array}$ & $\begin{array}{l}0.9617 \\
(-0.94)\end{array}$ & $\begin{array}{l}0.9557 \\
(-1.05)\end{array}$ & $\begin{array}{l}0.9317 \\
(-1.34)\end{array}$ & $\begin{array}{c}0.8375 * * * \\
(-8.97)\end{array}$ & $\begin{array}{c}0.9526 * * \\
(-2.20)\end{array}$ & $\begin{array}{l}0.9687 \\
(-1.48)\end{array}$ \\
\hline AGEN & $\begin{array}{l}0.7304 \\
(-0.21)\end{array}$ & $\begin{array}{l}0.8214 \\
(-0.13)\end{array}$ & $\begin{array}{l}0.8667 \\
(-0.09)\end{array}$ & $\begin{array}{c}1.5609^{*} \\
(1.78)\end{array}$ & $\begin{array}{l}1.3178 \\
(1.10)\end{array}$ & $\begin{array}{c}1.4298^{*} \\
(1.37)\end{array}$ & $\begin{array}{l}1.6672 \\
(0.99)\end{array}$ & $\begin{array}{c}3.3822 * * * * \\
(2.58)\end{array}$ & $\begin{array}{c}3.0049 * * \\
(2.09)\end{array}$ \\
\hline TECH & $\begin{array}{c}2.4702^{* * * *} \\
(2.68)\end{array}$ & $\begin{array}{c}2.2420^{* * *} \\
(2.37)\end{array}$ & & $\begin{array}{l}1.1090 \\
(1.15)\end{array}$ & $\begin{array}{l}1.0803 \\
(0.86)\end{array}$ & & $\begin{array}{c}0.4764 * * * \\
(-3.36)\end{array}$ & $\begin{array}{c}0.5945^{* *} \\
(-2.36)\end{array}$ & \\
\hline ULTI & $\begin{array}{l}1.5522^{*} \\
(1.41)\end{array}$ & $\begin{array}{l}1.5278^{*} \\
(1.25)\end{array}$ & $\begin{array}{c}1.5434^{*} \\
(1.35)\end{array}$ & $\begin{array}{c}4.3639^{* * * *} \\
(4.29)\end{array}$ & $\begin{array}{c}4.1842^{* * * *} \\
(3.96)\end{array}$ & $\begin{array}{c}3.3818 * * * * \\
(3.49)\end{array}$ & $\begin{array}{c}0.6662 * * * \\
(-2.99)\end{array}$ & $\begin{array}{c}0.4390^{* * * *} \\
(-5.92)\end{array}$ & $\begin{array}{c}0.4539 \text { *** } \\
(-5.65)\end{array}$ \\
\hline DUAL & & $\begin{array}{l}1.1011 \\
(0.78)\end{array}$ & $\begin{array}{l}1.1134 \\
(0.87)\end{array}$ & & $\begin{array}{l}1.6258 \\
(1.39)\end{array}$ & $\begin{array}{c}1.1632 * \\
(1.56)\end{array}$ & & $\begin{array}{l}1.1755 \\
(0.93)\end{array}$ & $\begin{array}{l}1.0620 \\
(0.34)\end{array}$ \\
\hline BOARD & & $\begin{array}{c}0.9721^{*} \\
(-1.46)\end{array}$ & $\begin{array}{l}0.9902 \\
(-0.46)\end{array}$ & & $\begin{array}{c}1.0569 * * * \\
(4.09)\end{array}$ & $\begin{array}{c}1.0367 * * \\
(2.22)\end{array}$ & & $\begin{array}{c}1.1099 * * * \\
(4.22)\end{array}$ & $\begin{array}{c}1.1304^{* * * *} \\
(5.08)\end{array}$ \\
\hline INDEP & & $\begin{array}{l}0.6116 \\
(-0.16)\end{array}$ & $\begin{array}{l}0.1948 \\
(-0.58)\end{array}$ & & $\begin{array}{c}0.0110^{*} \\
(-1.86)\end{array}$ & $\begin{array}{c}0.0159^{*} \\
(-1.68)\end{array}$ & & $\begin{array}{l}0.0013 \\
(-0.70)\end{array}$ & $\begin{array}{l}0.0010 \\
(-0.74)\end{array}$ \\
\hline D1 & & & $\begin{array}{l}1.2714 \\
(1.19)\end{array}$ & & & $\begin{array}{l}1.1564 \\
(0.99)\end{array}$ & & & $\begin{array}{c}0.5333^{*} \\
(-1.73)\end{array}$ \\
\hline D2 & & & $\begin{array}{c}3.3468^{* * * *} \\
(5.52)\end{array}$ & & & $\begin{array}{c}3.3776 * * * \\
(7.94)\end{array}$ & & & $\begin{array}{l}0.7364 \\
(-0.59)\end{array}$ \\
\hline D3 & & & $\begin{array}{c}1.6399 * * * \\
(3.62)\end{array}$ & & & $\begin{array}{c}1.9839 * * * \\
(7.19)\end{array}$ & & & $\begin{array}{c}2.0803^{* * * *} \\
(4.76)\end{array}$ \\
\hline D4 & & & $\begin{array}{c}0.3256^{* * * *} \\
(-3.13)\end{array}$ & & & $\begin{array}{c}1.4971 * * * \\
(2.84)\end{array}$ & & & $\begin{array}{l}1.3484 \\
(1.22)\end{array}$ \\
\hline Log likelihood & -343.6653 & -356.9119 & -335.8130 & -353.0820 & -331.3821 & -327.7450 & -2206.8484 & -1973.0827 & -1937.6440 \\
\hline LR Chi2(N) & 21.61 & 24.04 & 36.62 & 77.84 & 78.48 & 85.78 & 238.32 & 638.90 & 709.78 \\
\hline
\end{tabular}

Hazard ratios and $t$-statistics in (parentheses) are reported.

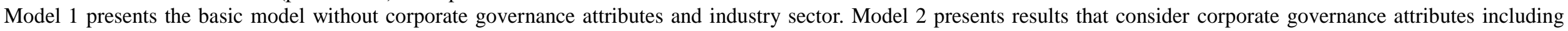
CEO duality, board size and board independence. Model 3 presents results that consider corporate governance attributes and industry sector.

$*(* *, * * *)$ denotes rejection of the null hypothesis at the $10 \%(5 \%, 1 \%)$ significance level.

Variable definitions are given in Table 1. 